\title{
STRATEGI DAN MEDIA PEMBELAJARAN PENDIDIKAN AGAMA ISLAM DI ERA PANDEMI COVID-19
}

\author{
Mardianto, Nirwana Anas, Sri Baniah, M. Anwar Sadat \\ Universitas Islam Negeri Sumatera Utara Medan \\ E-mail: mardianto@uinsu.ac.id, nirwanaanas@uinsu.ac.id, sribaniah07@gmail.com,mhd.anwarsadatqs@gmail.com
}

How to Cite:

Mardianto, Anas. N, Baniah. S, Sadat. M. A. (2021). Strategi dan Media Pembelajaran Pendidikan Agama Islam di Era Pandemi Covid-19. Fitrah: Journal of Islamic Education, 2(1), 13-24.

\section{ARTICLE HISTORY}

Received : 22 June 2021

Revised : 09 July 2021

Accepted : 12 July 2021

Published : 13 July 2021

\section{KEYWORDS:}

Covid-19 Era, Media, Learning, Islamic Religious Education, Strategy

\begin{abstract}
Strategy and media are important components in the learning process. In the era of the covid-19 pandemic, various strategies and learning media that have been used by teachers, do not seem to be able to play more roles through online learning. This is due to the design of learning strategies and media that have been intended face-to-face (offline, offline). This paper aims to analyze the appropriate strategies and media used in learning Islamic religious education (PAI) in the covid-19 era. This research uses a qualitative approach with a literature study method. Analyze and test the validity of the data using reference materials, including scientific articles, books, proceedings and final assignments (thesis, thesis, dissertation). The results of this study indicate that (1) the appropriate strategy used is distance learning strategy (PJJ). This is based on the stipulation of social distancing policies by the government towards the Indonesian people, including in the field of education; and (2) the right media to use is an online application in the form of WhatsApp Group, Google Classroom, E-Learning, Youtube, Google Meeting and Zoom.
\end{abstract}

\section{RIWAYAT ARTIKEL}

Diterima : 22 Juni 2021

Direvisi : 09 Juli 2021

Disetujui : 12 Juli 2021

Diterbitkan : 13 Juli 2021

\section{KATA KUNCI:}

Era Covid-19, Media, Pembelajaran, Pendidikan Agama Islam, Strategi

\section{ABSTRAK}

Strategi dan media adalah komponen penting dalam proses pembelajaran. Di era pandemi covid-19, berbagai strategi dan media pembelajaran yang selama ini digunakan oleh guru, tampaknya tidak dapat berperan lebih melalui pembelajaran daring. Hal ini disebabkan oleh desain strategi dan media pembelajaran yang selama ini diperuntukkan secara tatap muka (offline, luring). Tulisan ini bertujuan untuk menganalisa strategi dan media yang tepat digunakan dalam pembelajaran pendidikan agama Islam (PAI) di era covid-19. Penelitian ini menggunakan pendekatan kualitatif dengan metode studi kepustakaan. Analisa dan uji keabsahan data menggunakan bahan referensi, meliputi artikel ilmiah, buku, prosiding dan tugas akhir (skripsi, tesis, disertasi). Hasil penelitian ini menunjukkan bahwa (1) strategi yang tepat digunakan adalah strategi pembelajaran jarak jauh (PJJ). Hal ini didasarkan pada penetapan kebijakan social distancing oleh pemerintah terhadap masyarakat Indonesia, termasuk dalam bidang pendidikan; dan (2) media yang tepat digunakan adalah aplikasi online berupa Whats App Group, Google Classroom, E-Learning, Youtube, Google Meeting dan Zoom. 


\section{PENDAHULUAN}

Pendidikan agama Islam merupakan materi primer yang dibutuhkan oleh setiap individu (umat Islam) (Sada, 2017). Upaya pemenuhan kebutuhan ini, dilakukan secara komprehensif dan dijamin oleh undangundang (konstitusi bangsa Indonesia) (Pratama \& Zulhijra, 2019; Susanto \& Lestari, 2018). Sebab, materi keagamaan adalah hak setiap individu, yang dapat diajarkan melalui pendidikan formal, nonformal, terlebihlebih informal (Aisyah \& Amalia, 2020; Tang, 2019; Khakim, 2018). Inilah yang mendasari materi PAI wajib diajarkan sejak jenjang SD/MI sederajat sampai dengan pendidikan tinggi.

Pembelajaran PAI, lazimnya diajarkan di surau, dayah, atau pondok pesantren (lembaga pendidikan non-formal) (Anam, 2017; Afida, 2018; Khairuddin \& Assingkily, 2021), sekolah atau madrasah (lembaga pendidikan formal) (Hosnan, 2015) dan lingkungan keluarga (lembaga informal) (Putro, et.al., 2020). Varian cara mengajar dan media yang digunakan selama ini juga berbeda dan memiliki ciri khas. Sebut saja, aspek strategi meliputi; discovery learning (Anas \& Hasana, 2018), think pair share (Syarifah, et.al., 2016), active learning strategy (Ueckert \& Gess-Newsome, 2008), index card match (Rahayu \& Pramukantoro, 2013), card sort (Murti, et.al., 2017), everyone is a teacher here (Firdaus, 2018; Syahruddin, et.al., 2018), dan two stay two stray (Khaer, 2015). Sedangkan aspek media sebut saja seperti proyektor (Utami, 2017).

Kelaziman pembelajaran tersebut, tampaknya tidak efektif digunakan pada era pandemi Covid-19. Hal ini didasarkan penetapan kebijakan untuk melakukan pembatasan jarak skala sosial atau social distancing (Sit. \& Assingkily, 2020; Jusuf, et.al., 2020). Atas dasar ini, dibutuhkan strategi dan media yang tepat sebagai alternatif keberlanjutan pendidikan di era pandemi Covid-19.

Strategi dan media pembelajaran yang selama ini diterapkan semasa luring (tatap muka) berbeda dengan desain pembelajaran di era Covid-19. Hal ini disebabkan oleh cara belajar melalui media online dan strategi yang berbeda untuk diterapkan agar pembelajaran tetap efektif dilaksanakan via smartphone. Ditambah lagi, belum ada standarisasi pembelajaran dari pemerintah tentang belajar sistem online selama pandemi Covid-19.

Sejatinya, kajian strategi dan media pembelajaran era Covid-19 telah banyak diteliti sebelumnya. Adapun di antaranya membahas dari aspek blended learning (Istiningsih \& Hasbullah, 2015; Darma, et.al., 2020; Assingkily \& Sahlan, 2021; Utari, et.al., 2020; Putri, et.al., 2021), pengembangan dan desain pembelajaran era Covid-19 (Yuangga \& Sunarsi, 2020), motivasi belajar dan respons siswa terhadap pembelajaran daring (Firmansyah, 2021; Lusidawaty, et.al., 2020), pembelajaran online di perguruan tinggi (Puspitorini, 2020), perubahan strategi dan media pembelajaran (Ichsan, et.al., 2020; Azis, 2019; Yakobus, 2020; Mardianto, 2014), manajemen SDM (Bahri \& Arafah, 2020), dan fenomena dan pengaruh pembelajaran online terhadap hasil belajar siswa (Nur, 2017; Mardianto \& Assingkily, 2021).

Mencermati kajian literatur di atas, dipahami bahwa terdapat banyak aspek 
yang telah diteliti. Meskipun begitu, masih ditemukan "kekosongan ranah kajian" yakni terkait deskriptif strategi dan media yang tepat digunakan selama pembelajaran online perlu diteliti lebih lanjut. Adapun penelitian yang dimaksud, terangkum dalam judul, "Strategi dan Media Pembelajaran Pendidikan Agama Islam (PAI) di Era Pandemi Covid-19".

Melalui penelitian ini, diharapkan terdapat rekomendasi berbasis ilmiah tentang strategi dan media yang "layak" diterapkan dalam pembelajaran PAI selama masa pandemi Covid-19. Dengan demikian, pendidikan tetap berlanjut, meskipun situasi darurat pandemi Covid-19, melalui alternatif strategi dan media pembelajaran PAI yang direkomendasikan dalam penelitian ini.

\section{KAJIAN TEORI}

Secara umum, pengertian atau definisi strategi pembelajaran adalah suatu usaha menggunakan strategi yang sistematis dilakukan secara efektif untuk mencapai tujuan pembelajaran. Selanjutnya, secara khusus strategi pembelajaran dalam dunia pendidikan dapat dimaknai sebagai suatu kerangka (konsep) sekaligus metode yang digunakan sebagai alternatif memberi kemudahan mencapai tujuan pembelajaran (Nasution, 2017).

Dapat diringkas bahwa strategi pembelajaran adalah cara-cara yang akan dipilih dan digunakan oleh seorang pengajar untuk menyampaikan materi pembelajaran yang bertujuan untuk memudahkan peserta didik menerima dan memahami materi pembelajaran, yang pada akhirnya tujuan pembelajaran dapat dikuasainya di akhir kegiatan belajar. Strategi pembelajaran harus mengandung penjelasan tentang metode atau prosedur dan teknik yang digunakan selama proses pembelajaran berlangsung. Artinya, metode atau prosedur dan teknik pembelajaran merupakan bagian dari strategi pembelajaran. (Fuad, 2013)

Kemudian Strategi pembelajaran terdiri dari berbagai macam, di antaranya strategi inkuiri, yaitu kegiatan pembelajaran yang mengutamakan pada proses berpikir secara kritis dan analitis dalam melatih keterampilan berpikir siswa. Selain iu ada juga strategi ekspositoris, yaitu kegiatan pembelajaran yang mengutamakan pada proses pemberian materi ajar secara lisan oleh guru kepada siswa, dengan tujuan agar siswa terbantu dalam memahami materi ajar secara efektif (Nasution, 2017).

Pola sistem strategi pembelajaran daring (dalam jaringan) merupakan sistem pembelajaran jarak jauh tanpa tatap muka secara langsung antara guru dan siswa yang dilakukan melalui jaringan yang menggunakan jaringan internet. Guru dituntut cakap menggunakan media pembelajaran yang berbasis online dan memastikan kegiatan belajar mengajar tetap berjalan walaupun di masa pandemic Covid-19, meskipun siswa berada di rumah pembelajaran harus tetap dijalankan. Sehingga guru diharuskan mampu dan dapat mendesain media pembelajaran sebagai inovasi dengan memanfaatkan media daring (online). Hal ini sesuai dengan arahan Mendikbud Republik Indonesia terkait Surat Edaran Nomor 4 Tahun 2020 tentang Pelaksanaan Kebijakan Pendidikan dalam Masa Darurat Penyebaran Corona Virus 
Disease (COVID-19). Sistem pembelajaran dilaksanakan melalui perangkat Komputer atau laptop yang terhubung dengan koneksi jaringan internet. (Suhendro, 2020)

Guru dapat melakukan pembelajaran bersama di waktu yang bersamaan dengan menggunakan grup di media sosial seperti WhatsApp (WA), telegram, instagram, zoom, google classroom dan lain sebagainya. Dengan demikian, guru dapat memastikan siswa mengikuti pembelajaran dalam waktu yang bersamaan, meskipun di tempat yang berbeda. (Lubis et al., 2020)

Kemudian tekait dengan media pembelajara dalam beberapa literatur tidak terdapat perbedaan pengertian alat dan media pendidikan. Daradjat (1984: 80) menyebutkan pengertian alat pendidikan sama dengan media pendidikan, sarana pendidikan. Sedangkan dalam kepustakaan asing, sedangkan ahli menggunakan istilah audio visual aids (AVA), teaching material, instructional material.

Term alat berarti barang sesuatu yang dipakai untuk mencapai suatu maksud. Sedangkan media berasal dari bahasa latin dan bentuk jamak dari medium, secara harfiah berarti pelantara atau pengantar. Dalam hal media terdapat batasan rumusan para ahli seperti yang dikemukakan oleh Gagne dalam Sadiman (2017), media adalah berbagai jenis komponen dalam lingkungan siswa yang dapat merangsangnya untuk belajar. Dua definisi ini tampak pengertian media mengacu pada penggunaan alat yang berupa benda untuk membantu proses penyampaian pesan.

Sedangkan Vernous, dia menyebutkan bahwa media pendidikan adalah sumber belajar dan dapat juga diartikan dengan manusia dan benda atau peristiwa yang membuat kondisi siswa mungkin memperoleh pengetahuan, keterampilan atau sikap. Jadi Vernous berpendapat bahwa sarana pendidikan bukan hanya alat-alat yang biasa digunakan dalam proses belajar mengajar akan tetapi pengajar pun (guru) termasuk dari sarana alat pendidikan tersebut. Sehingga disebutkan bahwa pendapat Vernous ini jangkauanya lebih luas ketimbang batasan yang dikembangkan sebelumnya disamping alat yang berupa benda.

Dari beberapa literatur yang ada antara alat dan media pendidikan tidak dibedakan secara jelas, pada umumnya banyak yang mengindikasikan bahwa antara alat dan media itu tidak dapat dipisahkan dan dibedakan secara hitam putih. Dalam pendidikan Islam sarana merupakan faktor yang sangat urgen apalagi setelah kita tahu bahwa alat-alat pendidikan itu bukan hanya meliputi perangkat keras saja namun termasuk keteladanan guru.

Menurut pendapat para ahli media pendidikan memiliki beberapa manfaat di antaranya menurut Yusuf Hadi Miarso: membuat konkret konsep yang abstrak; membawa objek yang sukar didapat kepada lingkungan belajar siswa, menampilkan objek yang terlalu besar; mengamati gerakan yang terlalu cepat, memungkinkan keragaman pengamatan dan persepsi bagi pengalaman siswa, membangkitkan motivasi belajar, menyajikan informasibelajar secara konsisten dan dapat diulang maupun disimpan dalam menutur kebutuhan (Ramayulis, 2012). 


\section{METODE PENELITIAN}

Penelitian ini menggunakan pendekatan kualitatif dengan metode studi kepustakaan (library research). Adapun fokus pembahasan yaitu mengenai strategi dan media yang tepat digunakan di era pandemi Covid-19, khususnya pada pembelajaran pendidikan agama Islam (PAI). Data penelitian ini diperoleh melalui penelusuran bahan referensi ilmiah meliputi; buku, artikel, prosiding, dan tugas akhir (skripsi, tesis, disertasi), selanjutnya bahan referensi tersebut digunakan sebagai pengujian atau pengecekan keabsahan data.

\section{HASIL DAN PEMBAHASAN PENELITIAN}

\section{Strategi Pembelajaran PAI Era Covid-19}

Pembelajaran PAI merupakan materi urgen (penting) bagi penanaman karakter bagi siswa (Assingkily \& Miswar, 2020; Ainiyah \& Wibawa, 2013; Anwar \& Syaiful, 2018). Atas dasar ini, situasi Covid-19 bukan menjadi alasan materi ini dijeda sementara untuk diajarkan kepada siswa. Begitupun, dibutuhkan strategi yang tepat bagi pengelola satuan lembaga pendidikan (madrasah/ sekolah) dalam mengajarkan PAI bagi para anak atau siswa (Zein, 2016; Lubis, et.al., 2020).

Adapun strategi yang tepat digunakan dalam menyampaikan materi pembelajaran PAI bagi siswa ialah melalui strategi pembelajaran jarak jauk disingkat PJJ. Sebab, ini adalah alternatif yang baik bagi guru dan siswa dalam berinteraksi, serta tetap mematuhi protokol kesehatan (Latip, 2020; Simanjuntak \& Kismartini, 2020; Parlindungan, et.al., 2020; Kurniawan
\& Syahputra, 2013; Purnama, 2008). Lebih lanjut, ini adalah bagian upaya memutus mata rantai penyebaran Covid-19 di Indonesia melalui bidang pendidikan, serta tindak lanjut dari penerapan kebijakan social distancing (Sari, et.al., 2020; Herdiana, 2020). Strategi pembelajaran jarak jauh (PJ), memberi kemudahan bagi guru dalam menyampaikan materi kepada siswa dalam waktu bersamaan meskipun dari jarak yang berjauhan (Jason, et.al., 2021). Hal ini dipandang aman dan efektif, melihat kondisi "darurat kesehatan" yang belum diketahui kapan akan berakhir. Di samping itu, siswa juga memperoleh kemudahan dalam aspek interaksi pembelajaran dengan guru (Erdiansyah, 2020). Meskipun begitu, tidak dipungkiri masih terdapat beberapa kelemahan proses pembelajaran melalui strategi PJJ.

Adapun kelemahan strategi PJJ, di antaranya mencakup kendala jaringan (koneksi) internet, tidak tersampaikannya pesan (materi pembelajaran) secara utuh kepada siswa, serta yang terpenting aspek keteladanan seakan memudar dalam interaksi pembelajaran (Khoiriah \& Haryono, 2021; Marken, 2020). Padahal, materi pembelajaran PAI memprioritaskan aspek kepribadian guru yang patut diteladani oleh siswa. Bila dilaksanakan secara daring, maka siswa tidak dapat secara langsung mengamati perilaku guru saat mengajar, begitu juga sebaliknya guru terhadap siswa.

Menurut Sit. \& Assingkily, (2020) Penerapan pembelajaran jarak jauh meliputi strategi belajar via online dan belajar kunjungan. Pertama, pembelajaran dengan strategi via online, merupakan alternatif 
pembelajaran dalam masa pandemi Covid-19 (Ellanur, 2017). Mendukung pendapat ini, Mauly (2020) menuturkan bahwa pembelajaran dengan alternatif online sangat membantu praktisi pendidikan, pelajar, pendidik, dan banyak pihak dalam bidang pendidikan untuk melanjutkan pendidikan di tengah situasi pandemi Covid-19 secara efektif dan aman sesuai protokol kesehatan. Kedua, pembelajaran dengan strategi pola pembelajaran kunjungan. Menurut Naserly (2020), pembelajaran via online tidak selamanya menjamin kemudahan untuk belajar di era pandemi Covid-19. Hal ini dapat diamati dari kendala jaringan, dan lain sebagainya. Atas dasar ini, Ruhaena \& Ambarwati (2015) menawarkan pembelajaran dilakukan di rumah. Lebih lanjut, Awofala (2020) menyebutnya dengan istilah pola pembelajaran kunjungan ke rumah yang mirip homeschooling di era pandemi Covid-19. Dengan demikian, pembelajaran dengan strategi kunjungan bisa menjadi alternatif di tengah pandemi Covid-19.

Dengan demikian, dipahami bahwa strategi pembelajaran jarak jauh sangat membantu keberlanjutan pendidikan di Indonesia semasa pandemi Covid-19. Akan tetapi, tidak pula menutup kemungkinan kelemahan dalam proses dan dampaknya, terutama dalam aspek keteladanan yang ditampilkan guru kepada siswa, untuk membentuk kepribadian utuh pada diri siswa. Untuk itu, dibutuhkan suatu rumusan dari pemerintah Indonesia tentang standar pembelajaran online, sehingga tujuan dan target pembelajaran tetap dapat tercapai secara optimal.

\section{Media Pembelajaran PAI Era Covid-19}

Media pembelajaran berfungsi menyampaikan pesan antara pemberi pesan (guru) dan penerima pesan (siswa) (Zainiyati, 2013). Lebih dari itu, menurut Wahidin (2018) media juga dapat menghubungkan antara guru, siswa, sumber belajar, dan pesan (materi pembelajaran) itu sendiri. Pembelajaran PAI sebagai materi yang wajib dipatrikan kepada siswa (sejak usia dasar), harus memastikan media yang digunakan tepat untuk menyampaikan materi kepada siswa.

Dalam konteks ini, materi pembelajaran PAI dipandang sebagai materi yang mengajarkan siswa tentang keislaman, pengamalan dan pengalaman ibadah. Selanjutnya, materi PAI juga memuat kandungan membentuk kepribadian atau karakter siswa sesuai dengan tuntunan Islam (Budiman, 2013). Inilah yang menjadi dasar mengapa materi PAI sangat penting, yaitu aspek pembentukan kepribadian siswa.

Peran media pembelajaran dalam menyampaikan isi kandungan materi PAI kepada siswa sangat patut diperhatikan (Setiawan, 2019). Mengingat, kini pembelajaran telah ditetapkan melalui daring (online) dan pembelajaran jarak jauh. Adapun media yang tepat digunakan dalam kondisi social distancing akibat Covid-19 yaitu melalui aplikasi online berupa $W$ hats $A p p$, Google Classroom, E-Learning, Youtube, Google Meeting dan Zoom.

Media pembelajaran berbasis aplikasi online di atas, merupakan alternatif penghubung antara guru dan siswa dalam interaksi pembelajaran PAI selama era pandemi Covid-19 (Atsani, 2020). 
Adapun peran dalam konteks ini adalah menghubungkan dalam aspek pembelajaran, penugasan dan penilaian. Ini menunjukkan bahwa keberlanjutan pendidikan tetap dapat dihubungkan oleh media aplikasi online. Hanya saja, dari aspek kepribadian dan keteladanan belum dapat dihubungkan layaknya pembelajaran tatap muka.

Sesungguhnya dampak covid-19 berdampak terhadap semua sektor, baik pendidikan, sosial, maupun ekonomi. Dilihat dari fakta di lapangan banyak yang sedang terjadi, baik siswa maupun orangtua siswa yang tidak memiliki alat telekomunikasi dalam menunjang pembelajaran secara daring, sehingga pihak sekolah ikut memikirkan mencari solusi untuk mengantisipasi hal tersebut. Dengan salah satu cara beberapa siswa yang tidak memiliki handphone melakukan pembelajaran secara berkelompok, sehingga mereka melakukan aktivitas pembelajaran pun bersama. Mulai belajar melalui videocall yang dihubungkan dengan guru yang bersangkutan, diberi pertanyaan satu persatu, hingga mengabsen melalui VoiceNote yang tersedia di WhatsApp. Materi-materinya pun diberikan dalam bentuk video yang berdurasi kurang dari 2 menit. Permasalahan yang terjadi bukan hanya terdapat pada sistem media pembelajaran akan tetapi ketersediaan kuota yang membutuhkan biaya cukup tinggi harganya bagi siswa dan guru guna memfasilitasi kebutuhan pembelajaran daring. Kuota yang dibeli untuk kebutuhan internet menjadi melonjak dan banyak di antara orangtua siswa yang tidak siap untuk menambah anggaran dalam menyediakan jaringan internet.

\section{SIMPULAN}

Berdasarkan uraian hasil dan pembahasan di atas, disimpulkan bahwa (1) strategi yang tepat digunakan adalah strategi pembelajaran jarak jauh (PJJ) meliputi pembelajaran via online dan pola pembelajaran kunjungan ke rumah. Hal ini didasarkan pada penetapan kebijakan social distancing oleh pemerintah terhadap masyarakat Indonesia, termasuk dalam bidang pendidikan; dan (2) media yang tepat digunakan adalah platform pembelajaran daring, berupa WhatsApp, Google Classroom, E-Learning, Youtube, Google Meeting dan Zoom.

\section{DAFTAR PUSTAKA}

Afida, Ifa. (2018). "Historisitas Lembaga Pendidikan Islam di Indonesia" Falasifa: Jurnal Studi Keislaman, 9(1). http://ejournal.inaifas.ac.id/index. $\mathrm{php} /$ falasifa/article/view/97.

Ainiyah, Nur \& Nazar Husain Hadi Pranata Wibawa. (2013). "Pembentukan Karakter Melalui Pendidikan Agama Islam" Al-Ulum, 13(1). http://www. journal.iaingorontalo.ac.id/index.php/ $\mathrm{au} /$ article/view/179.

Aisyah, Nurul \& Dian Risky Amalia. (2020). "Pemenuhan Hak Anak Berkebutuhan Khusus (ABK) Perspektif HAM \& Pendidikan Islam di MINU Purwosari Metro Utara" Attractive: Innovative Education Journal, 2(1). http://www. attractivejournal.com/index.php/aj/ article/view/37.

Anam, Saeful. (2017). "Karakteristik dan Sistem Pendidikan Islam: Mengenal Sejarah Pesantren, Surau dan Meunasah di Indonesia" JALIE: Journal of Applied Linguistics and Islamic Education, 1(1). http:// ejournal.inkafa.ac.id/index. php/jalie-inkafa/article/view/52. 
Anas, Nirwana \& Hasana, NR. (2018). "Pengaruh Strategi Pembelajaran Discovery Terhadap Hasil Belajar IPA MIN Kota Medan" Nizhamiyah, 8(2). http://jurnaltarbiyah.uinsu. ac.id/index.php/nizhamiyah/article/ view/391.

Anwar, Syaiful \& Agus Salim. (2018). "Pendidikan Islam dalam Membangun Karakter Bangsa di Era Milenial" AlTadzkiyyah: Jurnal Pendidikan Islam, 9(2). http://www.ejournal.radenintan. ac.id/index.php/tadzkiyyah/article/ view/3628.

Assingkily, Muhammad Shaleh \& Miswar. (2020). "Urgensitas Pendidikan Akhlak Bagi Anak Usia Dasar (Studi Era Darurat Covid 19)" Tazkiya, 9(2). http://jurnaltarbiyah.uinsu.ac.id/ index.php/tazkiya/article/view/836.

Assingkily, Muhammad Shaleh \& Sahlan. (2021). "Blended Learning di UIN Sumatera Utara Medan: Historisitas \& Pengembangannya di Era Covid-19" Mudabbir: Journal Research and Education Studies, 1(1). http://jurnal. permapendis-sumut.org/index.php/ mudabbir/article/view/1.

Assingkily, Muhammad Shaleh. (2021). Penelitian Tindakan Kelas (Meneliti dan Membenahi Pendidikan dari Kelas). Medan: CV. Pusdikra Mitra Jaya.

Atsani, K.H. Lalu Gede Muhammad Zainuddin. (2020). “Transformasi Media Pembelajaran pada Masa Pandemi Covid-19" Al-Hikmah, 1(1). http:/ / ejournal.kopertais4.or.id/ sasambo/index.php/alhikmah/article/ view/3905.

Azis, Taufiq Nur. (2019). "Strategi Pembelajaran Era Digital" The Annual Conference on Islamic Education and Social Science, 1(2). http://pkm.uikabogor.ac.id/index.php/ACIEDSS/ article/view/512.

Bahri, Syamsul \& Novira Arafah.
(2020). "Analisis Manajemen SDM dalam Mengembangkan Strategi Pembelajaran di Era New Normal" Tafkir: Interdisciplinary Journal of Islamic Education, 1(1). https://pasca. jurnalikhac.ac.id/index.php/tijie/ article/view/2.

Budiman, Agus. (2013). "Efisiensi Metode dan Media Pembelajaran dalam Membangun Karakter Pembelajaran Pendidikan Agama Islam" At-Ta'dib: Journal of Pesantren Education, 8(1). https://ejournal.unida.gontor.ac.id/ index.php/tadib/article/view/514.

Darman, I Ketut, et.al. (2020). "Blended Learning, Inovasi Strategi Pembelajaran Matematika di Era Revolusi Industri 4.0 Bagi Pendidikan Tinggi” PRISMA: Prosiding Seminar Nasional Matematika, 3(1). https://journal. unnes.ac.id/sju/index.php/prisma/ article/view/37580.

Daradjat, Zakiah. (1984). Ilmu Pendidikan Islam. Jakarta: Bumi Aksara.

Erdiansyah, Rezi. (2020). "Social Distancing dan Hambatannya dalam Sosio-Kultural Indonesia" Surat Kabar, Kompas. http:// repository.untar.ac.id/13188/1/ buktipenelitian_10095004_19A163336. pdf.

Firdaus, Anugrah Ramadhan. (2018). "Application of Everyone is A Teacher Here Learning Model to Improve Self Confidence Students" Primaryedu: Journal of Primary Education, 2(2). http://e-journal.stkipsiliwangi.ac.id/ index.php/primaryedu/article / view/1007.

Firmansyah. (2021). "Motivasi Belajar dan Respon Siswa Terhadap Online Learning Sebagai Strategi Pembelajaran di Masa Pandemi Covid-19" Edukatif: Jurnal Ilmu Pendidikan, 3(2). https:// www.edukatif.org/index.php/ edukatif/article/view/355. 
Fuad, J. (2013). Strategi Pembelajaran Kooperatif (Studi Eksperimen). Tribakti: Jurnal Pemikiran Keislaman, 20(1), 40-56. https://doi. org/10.33367/tribakti.v20i1.94

Herdiana, Dian. (2020). "Social Distancing: Indonesian Policy Response to the Corona Virus Disease 2019 (Covid-19)" Jurnal Ilmu Administrasi, 17(1). http://180.250.247.102/index. $\mathrm{php} / \mathrm{jia} /$ article/view/555.

Hosnan, Mohammad. (2015). "Rekonstruksi Pembelajaran Tauhid Sebagai Fondasi Inovasi Pembelajaran Pendidikan Agama Islam (PAI) di Sekolah/ Madrasah" 'anil Islam: Jurnal Kebudayaan dan Ilmu Keislaman, 8(1). http://jurnal.instika.ac.id/index.php/ AnilIslam/article/view/34.

Ichsan, Ilmi Zajuli, et.al. (2020). "Covid-19 dan E-Learning: Perubahan Strategi Pembelajaran Sains dan Lingkungan di SMP" Jurnal Inovasi Pembelajaran, 6(1). https://ejournal.umm.ac.id/ index.php/jinop/article/view/11791.

Istiningsih, Siti \& Hasbullah. (2015). "Blended Learning, Trend Strategi Pembelajaran Masa Depan" Jurnal Elemen, 1(1). https://e-journal. hamzanwadi.ac.id/index.php/jel/ article/view/79

Jason, et.al. (2021). "Forecasting Social Distancing Impact on COVID-19 in Jakarta Using SIRD Model" Procedia Computer Science, 179(1). https://doi. org/10.1016/j.procs.2021.01.053.

Jusuf, Heni, et.al. (2020). "Pengaruh Pembelajaran Jarak Jauh Bagi Siswa SMA di Era Covid-19" Jurnal Kajian Ilmiah, 1(1). http://ejurnal.ubharajaya. ac.id/index.php/JKI/article/ view/212.

Khaer, Abu. (2015). "Meningkatkan Kemampuan Berpikir Kreatif Bangun Datar Melalui Strategi Two Stay Two Stray" Didaktikum, 16(3). http://i-rpp. com/index.php/didaktikum/article/ view/272.

Khairuddin \& Muhammad Shaleh Assingkily. (2021). "Urgensitas Mendirikan Madrasah di Samping Masjid (Studi Sejarah Pendidikan Islam Masa Pembaruan)" Edukasi Islami: Jurnal Pendidikan Islam, 10(01). http://jurnal.staialhidayahbogor.ac.id/ index.php/ei/article/view/1338.

Khakim, Abdul. (2018). "Hak Asasi Manusia dalam Perspektif Pendidikan Islam" Evaluasi: Jurnal Manajemen Pendidikan Islam, 2(1). https://e-journal.staimaalhikam.ac.id/index.php/evaluasi/ article/view/84.

Khoiriah, Olivia Nova \& Haryono. (2021). "Peran Orang Tua dalam Meningkatkan Semangat Belajar Kelas 6 SD Paramount Palembang di Masa Pandemi Covid-19" Prosiding Seminar Nasional, 1(1). https://jurnal. univpgri-palembang.ac.id/index.php/ Prosidingpps/article/view/5628.

Kurniawan, Helmi \& Dedek Agus Syahputra. (2013). "Perancangan Aplikasi Pembelajaran Jarak Jauh Sebagai Media Tambahan Pendukung Proses Belajar dan Mengajar" Semnasteknomedia Online, 3(1). https://ojs.amikom. ac.id/index.php/semnasteknomedia/ article/view/736.

Latip, Abdul. (2020). "Peran Literasi Teknologi Informasi dan Komunikasi pada Pembelajaran Jarak Jauh di Masa Pandemi Covid-19" EduTech: Jurnal Edukasi dan Teknologi Pembelajaran, 1(2). https:// ejurnal.umri.ac.id/index. $\mathrm{php} /$ eduteach/article/view/1956.

Lubis, Rahmat Rifai, et.al. (2020). "Pembelajaran Al-Qur'an Era Covid-19: Tinjauan Metode dan Tujuannya pada Masyarakat di Kutacane Aceh Tenggara" Kuttab: Jurnal Ilmu Pendidikan Islam, 4(2). http://journalfai.unisla.ac.id/index. 
$\mathrm{php} /$ kuttab/article/view/275.

Lubis, R. R., Mahrani, N., \& Nasution, L. M. (2020). Alternatif Strategi Pembelajaran Selama Pandemi Covid-19 Di STAI Sumatera Medan. ANSIRU PAI: Pengembangan Profesi Guru Pendidikan Agama Islam, 4(1), 1-16. http://dx.doi.org/10.30821/ansiru. v4i1.8065

Lusidawaty, Vivi, et.al. (2020). "Pembelajaran IPA dengan Strategi Pembelajaran Inkuiri untuk Meningkatkan Keterampilan Proses Sains dan Motivasi Belajar Siswa di Sekolah Dasar" Jurnal Basicedu: Journal of Elementary Education, 4(1). https://jbasic.org/ index.php/basicedu/article/view/333.

Mardianto. (2014). Psikologi Pendidikan: Landasan untuk Pengembangan Strategi Pembelajaran. Medan. Perdana Publishing.

Mardianto \& Muhammad Shaleh Assingkily. (2021). "Dosen Ngajar on the Road: Persepsi Mahasiswa tentang Fenomena Pembelajaran Era Covid-19" Jurnal Obsesi: Jurnal Pendidikan Anak Usia Dini, 6(1). https://obsesi.or.id/index. php/obsesi/article/view/1374.

Marken. (2020). "Efektivitas Pembelajaran Jarak Jauh (PJJ) Selama Pandemi Covid-19 di SDN 21 Sarang Burung Danau Kabupaten Sambas Kalimantan Barat" Jurnal Pendidikan Sains dan Aplikasinya, 3(2). https://journal. ikippgriptk.ac.id/index.php/JPSA/ article/view/2300.

Murti, Arum Kusuma, et.al. (2017). "Penerapan Strategi Card Sort pada Mata Pelajaran IPA Materi Sumbersumber Energi Terhadap Hasil Belajar Siswa Kelas II di SDN Brumbungan Semarang" Seminar Universitas PGRI Semarang, Prosiding Seminar Nasional HIMA dan Prodi PGSD 2017, 1(1). http://prosiding.upgris.ac.id/index. php/SD2017/pgsd20172/paper/ view $/ 2313 / 0$.

Nasution, Wahyuddin Nur. (2017). Strategi

Pembelajaran. Medan: Perdana Publishing.

Nur, Mohammad Djamil M. (2017). "Pengaruh Strategi Pembelajaran Fisika Berbasis Website Terhadap Hasil Belajar pada Siswa yang Memiliki Selfregulated Learning (SRL) yang berbeda" Edcomtech: Jurnal Kajian Teknologi Pendidikan, 2(1). http:// journal2.um.ac.id/index.php/ edcomtech/article/view/2078.

Parlindungan, Doby Putro, et.al. (2020). "Efektivitas Media Pembelajaran Berbasis Video Pembelajaran dalam Pembelajaran Jarak Jauh (PJJ) di SD Islam An-Nuriyah" Prosiding Seminar Nasional Penelitian LPPM UMJ, 1(1). https://jurnal.umj.ac.id/index.php/ semnaslit/article/view/8793.

Pratama, Irja Putra \& Zulhijra. (2019). "Reformasi Pendidikan Islam di Indonesia" Jurnal PAI Raden Fatah, 1(2). http://jurnal.radenfatah.ac.id/ index.php/pairf/article/view/3216.

Purnama, Bambang Eka. (2008). "Pemanfaatan Teknologi Wap Telepon Seluler untuk Media Pembelajaran Jarak Jauh" Journal Speed, 1(3). http://ijns. org/journal/index.php/speed/article/ view/1355.

Puspitorini, Ferawaty. (2020). "Strategi Pembelajaran di Perguruan Tinggi pada Masa Pandemi Covid-19" Jurnal Kajian Ilmiah, 1(1). http://ejurnal. ubharajaya.ac.id/index.php/JKI/ article/view/274.

Putri, Ayusi Perdana, et.al. (2021). "Strategi Pembelajaran Melalui Daring dan Luring Selama Pandemi Covid-19 di SD Negeri Sugihan 03 Bendosari" Prima Magistra: Jurnal Ilmiah Kependidikan, 2(1). http://www.uniflor.ac.id/ejournal/index.php/JPM/article/ view/728. 
Putro, Khamim Zarkasih, et.al. (2020). "Pola Interaksi Anak dan Orangtua Selama Kebijakan Pembelajaran di Rumah" Fitrah: Journal of Islamic Education, 1(1). http://jurnal.staisumateramedan.ac.id/index.php/fitrah/article/ view/12.

Rahayu, Astining \& Jusuf Austerawan Pramukantoro. (2013). "Pengaruh Model Pembelajaran Think Pair Share dengan Strategi Index Card Match Terhadap Hasil Belajar Siswa pada Standar Kompetensi Menerapkan Dasar-dasar Elektronika di SMK Negeri 1 Madiun" Jurnal Pendidikan Teknik Elektro, 2(3). https:// jurnalmahasiswa.unesa.ac.id/index. php/jurnal-pendidikan-teknik-elektro/ article/view/4723.

Ramayulis. (2012). Ilmu Pendidikan Islam. Jakarta: Kalam Mulia.

Sada, Heru Juabdin. (2017). "Kebutuhan Dasar Manusia dalam Perspektif Pendidikan Islam" Al-Tadzkiyyah: Jurnal Pendidikan Islam, 8(2). http:// www.ejournal.radenintan.ac.id/index. $\mathrm{php} /$ tadzkiyyah/article/view/2126.

Sadiman, Arif. S. (2017). Media Pendidikan: Pengertian Pengembangan dan Pemanfaatan. Jakarta: Pustekom Dikbud dan CV. Rajawali.

Sari, Widya, et.al. (2020). “Analisis Kebijakan Pendidikan Terkait Implementasi Pembelajaran Jarak Jauh pada Masa Darurat Covid 19" Jurnal Mappesona, 2(2). https://jurnal.iain-bone.ac.id/ index.php/mappesona/article/ view/830.

Setiawan, Agus. (2019). "Merancang Media Pembelajaran PAI di Sekolah (Analisis Implementasi Media Pembelajaran Berbasis PAI)" Darul Ulum, 10(2). https:// ejournal.stitdukotabaru.ac.id/ index.php/darululum/article/view/39.

Simanjuntak, Sri Yunita \& Kismartini. (2020). "Respon Pendidikan Dasar
Terhadap Kebijakan Pembelajaran Jarak Jauh Selama Pandemi Covid-19 di Jawa Tengah" Jurnal Ilmiah Wahana Pendidikan, 6(3). http://jurnal. peneliti.net/index.php/JIWP/article/ view/371.

Sit., Masganti \& Muhammad Shaleh Assingkily. (2020). "Persepsi Guru tentang Social Distancing pada Pendidikan AUD Era New Normal" Jurnal Obsesi: Jurnal Pendidikan Anak Usia Dini, 5(2). https://www. obsesi.or.id/index.php/obsesi/article/ view/756.

Suhendro, E. (2020). Strategi Pembelajaran Pendidikan Anak Usia Dini di Masa Pandemi Covid-19. Golden Age: Jurnal Ilmiah Tumbuh Kembang Anak Usia Dini, 5(3), 133-140. https://doi. org/10.14421/jga.2020.53-05

Susanto, Nanang Hasan \& Cindy Lestari. (2018). "Problematika Pendidikan Islam di Indonesia: Eksplorasi Teori Motivasi Abraham Maslow dan David McClelland" Edukasia Islamika: Jurnal Pendidikan Islam, 3(2). http://ejournal.iainpekalongan.ac.id/index. php/edukasiaislamika/article / view/1687.

Syahruddin, et.al. (2018). "Pengaruh Strategi Everyone is A Teacher Here (ETH), Contextual Teaching and Learning (CTL), dan Crossword Puzzle (CWP) serta Motivasi Belajar Terhadap Hasil Belajar Siswa pada Mata Pelajaran Bahasa Arab di MTs. Darul Falah Aek Songsongan" Ittihad: Jurnal Pendidikan, 1(2). http://ejournalittihad.alittihadiyahsumut.or.id/index. $\mathrm{php} /$ ittihad/article/view/20.

Syarifah, Hindun, et.al. (2016). "Pengaruh Strategi Pembelajaran Reading Questioning and Answering (RQA) Dipadu Think Pair Share (TPS) Terhadap Keterampilan Metakognitif Siswa Laki-laki dan Perempuan SMAN di Kota Malang" Jurnal Pendidikan, 
1(5). http://journal.um.ac.id/index. $\mathrm{php} / \mathrm{jptpp} /$ article/view/6259.

Tang, Ahmad. (2019). "Hak-hak Anak dalam Pasal 54 UU No. 35 Tahun 2014 tentang Perlindungan Anak" Jurnal Al-Qayyimah, 2(2). https:// www.jurnal.iain-bone.ac.id/index.php/ alqayyimah/article/view/ 654 .

Ueckert, Catherine Wilcoxson \& Julie GessNewsome. (2008). "Active Learning Strategies" The Sicence Teacher, 75(9). https://www.proquest.com/openview /08cef263a55ac004fbb0778f9a195d6d $/ 1$ ?pq-origsite $=$ gscholar\&cbl $=40590$.

Utami, Yulia. (2017). "Pengaruh Pemanfaatan Media Pembelajaran Proyektor LCD Menggunakan Program Power Point Terhadap Hasil Belajar Siswa dalam Menentukan Volume Kubus dan Balok pada Bangun Ruang” Jurnal Mantik Penusa, 1(1). http://ejurnal.pelitanusantara.ac.id/index.php/ mantik/article/view/300.

Utari, Widi, et.al. (2020). "Blended Learning: Strategi Pembelajaran Alternatif di Era New Normal" Prosiding Seminar Nasional Pendidikan, 2(1). https:// prosiding.unma.ac.id/index.php/ semnasfkip/article/view/330.

Wahidin, Unang. (2018). "Implementasi Literasi Media dalam Proses Pembelajaran Pendidikan Agama Islam dan Budi Pekerti” Edukasi Islami: Jurnal Pendidikan Islam, 7(02). https://jurnal. staialhidayahbogor.ac.id/ei/article/ view/284.

Yakobus. (2020). "Strategi Pembelajaran Daring Berbasis Multimedia di SMA Negeri 1 Menjalin Kabupaten Landak Provinsi Kalimantan Barat" Jurnal Pendidikan \& Sosial, 1(1). http:// ejournal.yudhaenglishgallery.com/ index.php/Jardiknas/article/view/7.

Yuangga, Kharisma Danang \& Denok Sunarsi. (2020). "Pengembangan Media dan Strategi Pembelajaran untuk
Mengatasi Permasalahan Pembelajaran Jarak Jauh di Pandemi Covid-19" JGK (Jurnal Guru Kita), 4(3). https://jurnal. unimed.ac.id/2012/index.php/jgkp/ article/view/19472.

Zainiyati, Husniyatus Salamah. (2013). "Media Pembelajaran PAI: Teori dan Aplikasinya" IAIN Sunan Ampel Press. http://digilib.uinsby.ac.id/20148/.

Zein, Muh. (2016). "Peran Guru dalam Pengembangan Pembelajaran" Jurnal Inspiratif Pendidikan, 5(2). http://103.55.216.56/index.php/ Inspiratif-Pendidikan/article / view/3480. 